\title{
A novel method for removing polyethyleneimine from biopharmaceutical samples: improving assay sensitivity of residual DNA qPCR
}

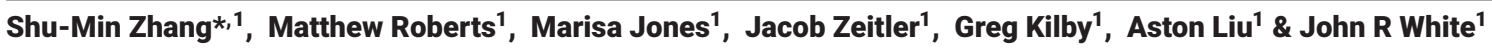 \\ ${ }^{1}$ Structure \& Function Characterization, CMC Analytical, GlaxoSmithKline, Collegeville, PA, USA; *Author for correspondence: ShuMin.2.Zhang@gsk.com
}

BioTechniques 68: 353-358 (June 2020) 10.2144/btn-2020-0011

First draft submitted: 27 January 2020; Accepted for publication: 12 March 2020; Published online: 31 March 2020

\section{ABSTRACT}

Polyethyleneimine (PEI) is a flocculent that is widely used in the downstream purification of monoclonal antibodies. It is an in-process residual that is carried through the drug purification process and strongly inhibits residual DNA quantitation by real-time quantitative PCR assay. Very high sample dilutions (e.g., 1:10,000) can overcome the interference of PEl, but at the cost of DNA assay sensitivity. Diluting samples poses a significant risk to the assay sensitivity needed to satisfy regulatory requirements on the quantitation of residual genomic DNA present per dose (i.e., $10 \mathrm{ng} /$ dose). Removing PEI while retaining DNA, by the use of sodium dodecyl sulfate, heparin and/or sarkosyl can overcome the interference of PEI and allow a more accurate quantitation of residual DNA.

\section{METHODSUMMARY}

A method to remove PEI from samples by the addition of heparin and sarkosyl or sodium dodecyl sulfate and $\mathrm{NaOH}$ is described. Different samples were spiked with DNA and the recovery quantitated by Wako/Kingfisher DNA extraction and qPCR or droplet digital PCR, as outlined in Figure 1.

\section{KEYWORDS}

heparin • host cell DNA • PEI • qPCR • sarkosyl • spike recovery

Detecting and quantifying residual host cell DNA is an essential impurity test for all biopharmaceutical products; levels of residual DNA must be closely monitored and controlled throughout the production and release of the drug substance. qPCR is a widely accepted approach for the quantification of residual DNA in recombinant therapeutic proteins [1-3] and the TaqMan qPCR system is widely used for quantification of residual host cell DNA [1,2,4-6].

Polyethyleneimine (PEI) is an organic compound that can be linear, low or highly branched and is strongly cationic. It binds strongly to the negatively charged backbone of duplex DNA [7] and is used as a flocculent to remove cell debris in the downstream purification process. It has been used successfully with microbial cell culture and might, in the future, be used as an alternative separation strategy for Chinese hamster ovary ( $\mathrm{CHO}$ ) cell-based downstream purification processes used in biopharmaceutical production [8]. PEI has also been widely used as a nonviral vector for gene therapy and transfection [9]. However, trace amounts of PEI inhibit a number of assays, including the detection of residual host cell DNA by qPCR.

Downstream purification experience has demonstrated that PEI concentrations can range from 100 p.p.m. (0.01\% w/v) for in-process samples to 20 p.p.m. $(0.002 \% \mathrm{w} / \mathrm{v})$ PEI in bulk drug substance (BDS). Such PEI concentrations require dilutions of between 2000 and 10,000-fold to achieve acceptable recovery of DNA (between 60 and 140\%) by qPCR analysis. Overcoming PEI interference is very important and challenging; our previous efforts with a large amount of work have unfortunately all failed.

Moret [10] and Bertschinger [11] reported that heparin can interfere with the PEI-DNA complex in vitro, as demonstrated using plasmid DNA and agarose gel electrophoresis. Heparin has a strong negative charge and is used clinically as an anticoagulant (blood thinner). It binds to PEI competitively, displacing DNA from the PEI-DNA complex. However, heparin alone at high concentrations (750 $\mu \mathrm{g} / \mathrm{ml})$ did not result in efficient removal of PEI according to a DNA qPCR assay (Table 1). Given this limitation, we explored alternative methods to increase the recovery of DNA.

Sarkosyl (sodium N-lauroyl sarcosinate) is an anionic surfactant which has been used extensively for cell lysis and protein solubilization [12]. We hypothesized that since sarkosyl is a surface activator with a net negative charge, it might work - either alone or cooperatively with heparin - to displace PEI and increase DNA recovery.

To test whether the combination of heparin and sarkosyl had an advantage over heparin treatment alone, PEI (1000 p.p.m., $0.1 \%$ w/v) and CHO DNA $(100 \mathrm{ng} / \mathrm{ml})$ in water were mixed and treated with heparin $(750 \mu \mathrm{g} / \mathrm{ml})$ and sarkosyl $(3 \% \mathrm{w} / \mathrm{v})$. Finally, the mixture was 


\begin{tabular}{|c|c|c|c|}
\hline Experimental conditions & Dilution & $\begin{array}{l}\text { Calculated PEI concentration after } \\
\text { dilution (p.p.m.) }\end{array}$ & $\begin{array}{l}\text { Recovery of } 100 \mathrm{ng} / \mathrm{ml} \text { DNA following treatment } \\
\text { and dilution (\%) }\end{array}$ \\
\hline Control (no PEI) & 2000 & 0 & $51.5 \pm 4.4$ \\
\hline Control (no PEI) + heparin + sarkosyl & 2000 & 0 & 89.8 \\
\hline \multirow[t]{2}{*}{ Control (PEI only) } & 10,000 & 0.1 & $11.6 \pm 1.3$ \\
\hline & 2000 & 0.5 & 0 \\
\hline \multirow[t]{2}{*}{ PEI + heparin $(750 \mu \mathrm{g} / \mathrm{ml})+3 \%$ sarkosyl } & 2000 & 0.5 & $58.6 \pm 6.9$ \\
\hline & 500 & 2 & $49.8 \pm 7.4$ \\
\hline \multirow[t]{2}{*}{$\mathrm{PEI}+$ heparin $(750 \mu \mathrm{g} / \mathrm{ml})$} & 10,000 & 0.1 & $12.5 \pm 1.0$ \\
\hline & 2000 & 0.5 & 0 \\
\hline \multirow[t]{2}{*}{ PEI + 1.5\% sarkosyl } & 500 & 2 & $69.9 \pm 5.0$ \\
\hline & 100 & 10 & $63.3 \pm 5.3$ \\
\hline \multirow[t]{2}{*}{ PEI + 3\% sarkosyl } & 500 & 2 & $68.1 \pm 6.9$ \\
\hline & 100 & 10 & $52.8 \pm 15.8$ \\
\hline
\end{tabular}

PEl: Polyethyleneimine.

$$
\begin{gathered}
\text { PEI } \\
\text { 200-2000 ppm } \\
+
\end{gathered}
$$
(50 ul)

Water, in-process sample of BDS
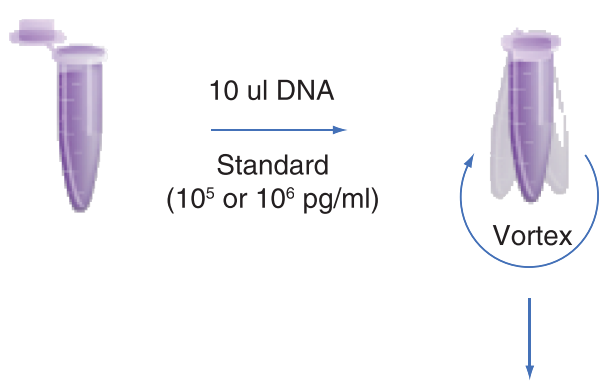

Add
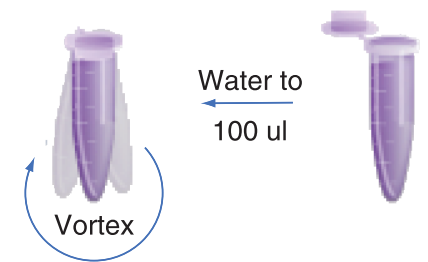

Heparin (80-750 ug/ml)

Sarkosyl $(0.3-3 \% \mathrm{w} / \mathrm{v})$

Incubate $25^{\circ} \mathrm{C}$

$10 \mathrm{~min}$ to allow

PEI \& DNA binding

Centrifuge $10 \mathrm{~min}$

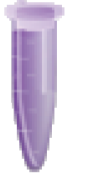

$$
\longrightarrow \text { 14,000 rpm }
$$

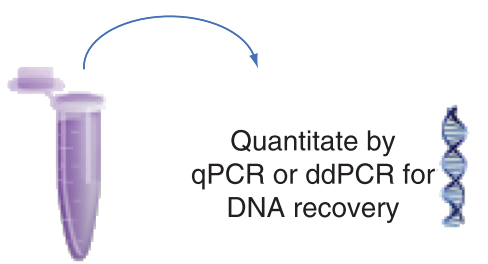

Incubate $90^{\circ} \mathrm{C}$

10 min heat block

Figure 1. Experiment procedures. Sample preparation, spiking of DNA and addition of polyethyleneimine followed by processing and DNA detection by qPCR or ddPCR.

BDS: Bulk drug substance;PEI: Polyethyleneimine.

diluted between 100- and 10,000-fold and analyzed for DNA recovery by Kingfisher or Wako DNA extraction followed by qPCR quantitation after dilution. The experimental procedure is outlined in Figure 1.

Table 1 shows a comparison of DNA recovery percentages from water spiked with DNA, PEI and treated with heparin, sarkosyl or combinations of both, and followed by sample dilution, Kingfisher DNA extraction and quantitation of CHO DNA by qPCR.

No DNA was detected in the PEl-only control (no treatment) at 2000 -fold dilution, and only $10 \%$ of the DNA was recovered at 10,000 fold dilution, indicating that PEI was still interfering with DNA quantitation. Treatment with a combination of heparin (750 $\mu \mathrm{g} / \mathrm{ml})$ and 


\begin{tabular}{|c|c|c|}
\hline Sample dilution & $\begin{array}{l}\text { Recovery of DNA at different sample dilutions: \% CHO-DNA recovery } \\
\text { with } 100 \text { p.p.m. PEI (control conditions) }\end{array}$ & $\begin{array}{l}\text { Recovery of DNA at different sample dilutions: \% CHO-DNA recovery } \\
\text { with } 100 \text { p.p.m. PEl, treated with heparin }(80 \mu \mathrm{g} / \mathrm{ml}) \text { and sarkosyl } \\
(0.15 \% \mathrm{w} / \mathrm{v})\end{array}$ \\
\hline 50 & & 82.4 \\
\hline 100 & & 101.1 \\
\hline 200 & 0.0 & 136.0 \\
\hline 1000 & 12.8 & \\
\hline 5000 & 71.7 & \\
\hline
\end{tabular}

sarkosyl $(3 \% \mathrm{w} / \mathrm{v})$ resulted in high recovery of DNA at both 500 -fold and 2000 -fold dilution. This recovery was comparable with the control recovery at 2000 -fold dilution $(51.5 \% \pm 4.4 \%)$. We next tried to determine whether both heparin and sarkosyl were needed for PEI removal. Heparin alone failed to remove a substantial amount of PEI and resulted in low DNA recovery $(12.5 \% \pm 1.0 \%)$ at 10,000 -fold dilution, which was no better than the PEI-only control. However, treatment with 1.5 or $3 \%$ sarkosyl allowed lower dilutions (1:100) to yield measurable quantities of DNA detection (between $52.8 \pm 8.7 \%$ and $63.3 \pm 5.3 \%$ recovery, compared with $10.9 \pm 1.3 \%$ recovery with no treatment) at a 10,000-fold dilution. This demonstrates that a substantial quantity of PEI was removed by the treatment with sarkosyl alone and that heparin was not needed for the removal of PEI in water.

\section{Quantitation of DNA in phenyl eluate (in process sample) with 100 p.p.m. PEI}

Phenyl-sepharose columns are commonly employed as a polishing step in monoclonal antibody production; thus the quantitation of DNA contamination is important when optimizing column elution conditions. After establishing that sarkosyl increased the recovery of DNA from water samples treated with PEI, we continued to explore the use of heparin and sarkosyl to recover DNA from PEI-spiked in-process samples. The results of phenyl-sepharose elution treatment are shown in Table 2. The PEI + CHO DNA control (no heparin and sarkosyl treatment) demonstrated $0.0 \%$ recovery at a 1:200 dilution and only increased to a reasonable recovery level (71.7\%) when diluted 5000-fold. However, with heparin and sarkosyl treatment, highly quantifiable levels of DNA were detected in as little as 1:50 dilution and $100 \%$ recovery was achieved at 200 -fold dilution. Thus, treatment with heparin and sarkosyl leads to a highly quantifiable level of DNA recovery with minimal dilution. Achieving the same level of DNA recovery at 100-times lower dilution indicates that the assay sensitivity improved 100 -fold.

\section{Quantitation of DNA in bulk drug substance}

Accurate and precise quantification of residual $\mathrm{CHO}$ genomic DNA in the bulk drug substance (BDS) sample matrix is critical. In addition, BDS samples contain high protein concentrations (usually $>100 \mathrm{mg} / \mathrm{ml}$ ), which can make the quantitation of DNA challenging.

Three BDS samples A, B, and C, representing different antibody targets and all belonging to the IgG1 isotype, were used to explore the ability of heparin + sarkosyl to remove PEI (20 p.p.m.) spiked into them. PEI + BDS was tested with the same combinations as previously (heparin, sarkosyl, heparin + sarkosyl in different concentrations). Each of these conditions resulted in a jelly-like state after heating and therefore all further work was stopped.

Bertschinger et al. [11] suggested that $\mathrm{NaOH}$ would help heparin to displace PEI from DNA. Since sarkosyl demonstrated an ability to disrupt the PEI-DNA interaction, sodium dodecyl sulfate (SDS, a detergent chemically similar to sarkosyl) and $\mathrm{NaOH}$ were tested with BDS samples containing 20 p.p.m. PEI.

Product A BDS spiked with PEI (20 p.p.m.) was treated with a number of combinations including: sarkosyl (1\% w/v) $+\mathrm{NaOH}(5 \mathrm{mM})$; $\operatorname{SDS}(1 \% \mathrm{w} / \mathrm{v})+\mathrm{NaOH}(5 \mathrm{mM})$; and sarkosyl $(1 \% \mathrm{w} / \mathrm{v})+\mathrm{NaOH}(1 \mathrm{mM})+\mathrm{NaCl}(150 \mathrm{mM})$ [11] following the experiment procedure outlined in Figure 1. In this set of experiments, droplet digital PCR (ddPCR) [13,14] was used without DNA extraction because ddPCR is faster and less labor-intensive than Wako DNA extraction combined with qPCR. Sample dilutions tested were 1:500 and 1:100.

As can be seen in Figure 2 (columns 4 and 5), for BDS A, the best condition for recovering DNA was SDS (1\% w/v) and NaOH (5 mM). Other conditions tested included sarkosyl $(1 \% \mathrm{w} / \mathrm{v})+\mathrm{NaOH}(5 \mathrm{mM})$, and sarkosyl $(1 \% \mathrm{w} / \mathrm{v})+\mathrm{NaOH}(1 \mathrm{mM})+\mathrm{NaCl}(150 \mathrm{mM})(\mathrm{columns}$ 2 and 3; columns 6 and 7); these combinations resulted in no quantifiable recovery of DNA. We also examined other conditions to remove $\mathrm{PEI}$, including using varying amounts of SDS and fine-tuning the concentration of $\mathrm{NaOH}$ to determine the optimal concentrations of SDS and $\mathrm{NaOH}$. As seen in Figure 3, increasing DNA recovery was observed down to an SDS concentration of $0.5 \% \mathrm{w} / \mathrm{v}(\mathrm{NaOH}$ concentration was $5 \mathrm{mM}$; columns $1-3)$, until SDS concentrations lower than $0.5 \%$ SDS w/v were used $(0.4-0.1 \% \mathrm{w} / \mathrm{v}$; columns 4 and 5). However, increasing the $\mathrm{NaOH}$ concentration twofold resulted in DNA recovery close to $50 \%$ at an SDS concentration of $1.0 \%$ (44.8\% recovery; columns 2 and 6). Figure 4 (columns 4-6) indicates that $\mathrm{NaOH}$ concentrations of between 25 and $35 \mathrm{mM}$ provided the optimal conditions for recovering DNA with yields of $120 \%$. SDS $(0.5 \% \mathrm{w} / \mathrm{v})+\mathrm{NaOH}(25 \mathrm{mM})$ proved to be the best conditions of those tested.

Wako DNA extraction coupled with qPCR is an industry standard method for host cell residual DNA testing of biopharmaceutical products. BDS samples of products A, B and C were spiked with 20 p.p.m. PEl and treated with SDS $(0.5 \% \mathrm{w} / \mathrm{v})+\mathrm{NaOH}(25 \mathrm{mM})$. Sample preparation procedures followed the experiment procedure outlined in Figure 1 . The data in Figure 5 show spike recoveries above $60 \%$ for 

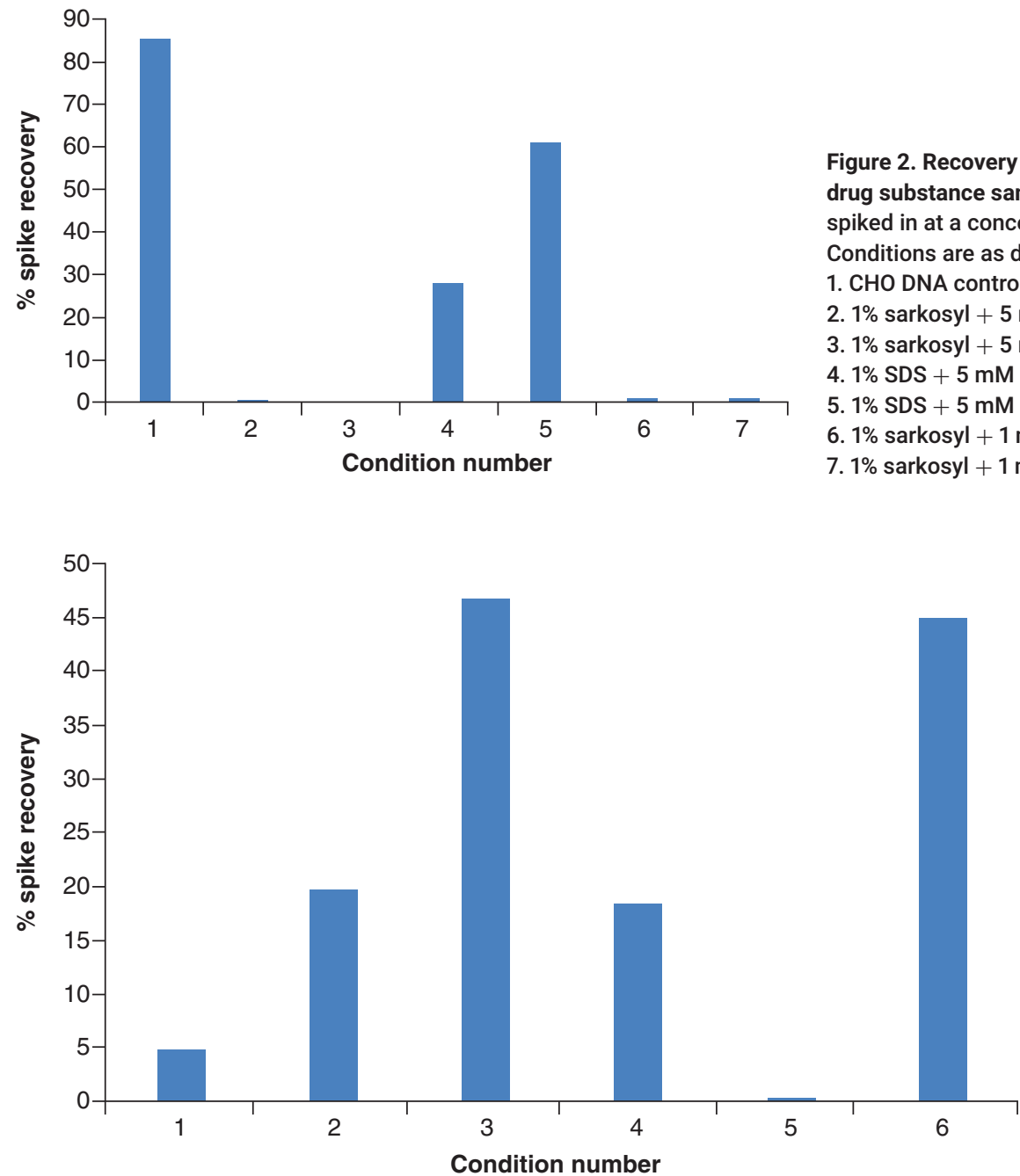

Figure 3. Effect of removing polyethyleneimine from bulk drug substance with different concentrations of SDS and NaOH. Bulk drug substance was spiked with 20 p.p.m. polyethyleneimine plus $10^{4} \mathrm{pg} / \mathrm{ml} \mathrm{CHO} \mathrm{DNA}$ and treated with SDS and $\mathrm{NaOH}$ as described below. Following dilution (1:100), DNA was quantified by ddPCR.

1. $1.5 \% \mathrm{SDS}+5 \mathrm{mM} \mathrm{NaOH}$;

2. $1.0 \% \mathrm{SDS}+5 \mathrm{mM} \mathrm{NaOH}$;

3. $0.5 \% \mathrm{SDS}+5 \mathrm{mM} \mathrm{NaOH}$;

4. $0.4 \% \mathrm{SDS}+5 \mathrm{mM} \mathrm{NaOH}$;

5. $0.1 \% \mathrm{SDS}+5 \mathrm{mM} \mathrm{NaOH}$;

6. $1.0 \% \mathrm{SDS}+10 \mathrm{mM} \mathrm{NaOH}$.

all three BDS samples at 1:200 dilution (columns 2, 4 and 6). Without treatment, BDS containing 20 p.p.m. PEI needed to be diluted 1:2000 to achieve $\geq 60 \%$ spike recovery. SDS $(0.5 \% \mathrm{w} / \mathrm{v})+\mathrm{NaOH}(25 \mathrm{mM})$ treatment improved the assay sensitivity approximately tenfold.

\section{Conclusion}

PEI interferes with DNA quantitation unless there is excessive dilution, which in turn can lead to an underestimation of total DNA in a product. The removal of PEI from in-process and BDS samples has proven challenging for the biopharmaceutical industry. To achieve efficient PEI removal, heparin $(750 \mu \mathrm{g} / \mathrm{ml})+$ sarkosyl $(3 \% \mathrm{w} / \mathrm{v})$ for PEI (1000 p.p.m.), and heparin $(80 \mu \mathrm{g} / \mathrm{ml})+\mathrm{sarkosyl}(0.15 \%$ w/v) for PEI (100 p.p.m.) increased qPCR assay sensitivity for water and in-process samples by $5-100-$ fold. It is recommended that $\mathrm{PEI} /$ heparin/sarkosyl are applied at this ratio. Using an analytical approach, we have demonstrated that a combination of SDS (0.5\% $\mathrm{w} / \mathrm{v}$ ) and $\mathrm{NaOH}(25 \mathrm{mM}$ ) effectively eliminates PEI (at 20 p.p.m.) from interfering in the assay, and increases assay sensitivity tenfold for BDS samples. The removal of any interfering agent from BDS and accurate quantitation of DNA are important for ensuring patient safety. With this improvement, it is possible to quantify residual host cell DNA by qPCR in alignment with industry guidelines on residual host cell DNA content of parenteral injections. 


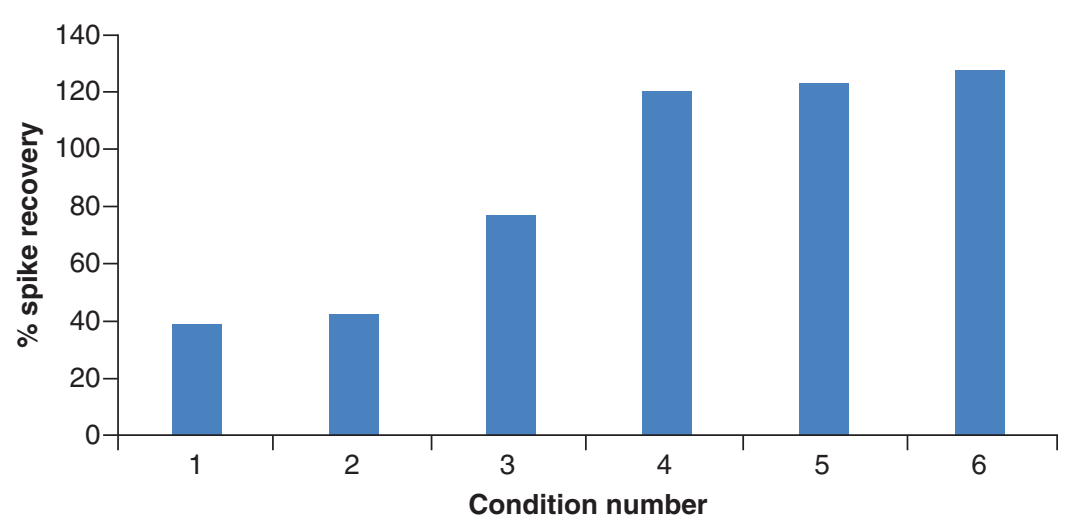

Figure 4. Effect of removing polyethyleneimine from bulk drug substance with further fine tuning of $\mathrm{NaOH}$ conditions. Bulk drug substance was spiked with 20 p.p.m. polyethyleneimine plus $10^{4} \mathrm{pg} / \mathrm{ml} \mathrm{CHO}$ DNA and treated with SDS (0.5\%) and $\mathrm{NaOH}(10-35 \mathrm{mM})$ as described below. Following dilution (1:100), DNA was quantified by ddPCR.

1. $0.5 \% \mathrm{SDS}+10 \mathrm{mM} \mathrm{NaOH}$;

2. $0.5 \% \mathrm{SDS}+15 \mathrm{mM} \mathrm{NaOH}$;

3. $0.5 \% \mathrm{SDS}+20 \mathrm{mM} \mathrm{NaOH}$;

4. $0.5 \% \mathrm{SDS}+25 \mathrm{mM} \mathrm{NaOH}$

5. $0.5 \% \mathrm{SDS}+30 \mathrm{mM} \mathrm{NaOH}$

6. $0.5 \% \mathrm{SDS}+35 \mathrm{mM} \mathrm{NaOH}$.

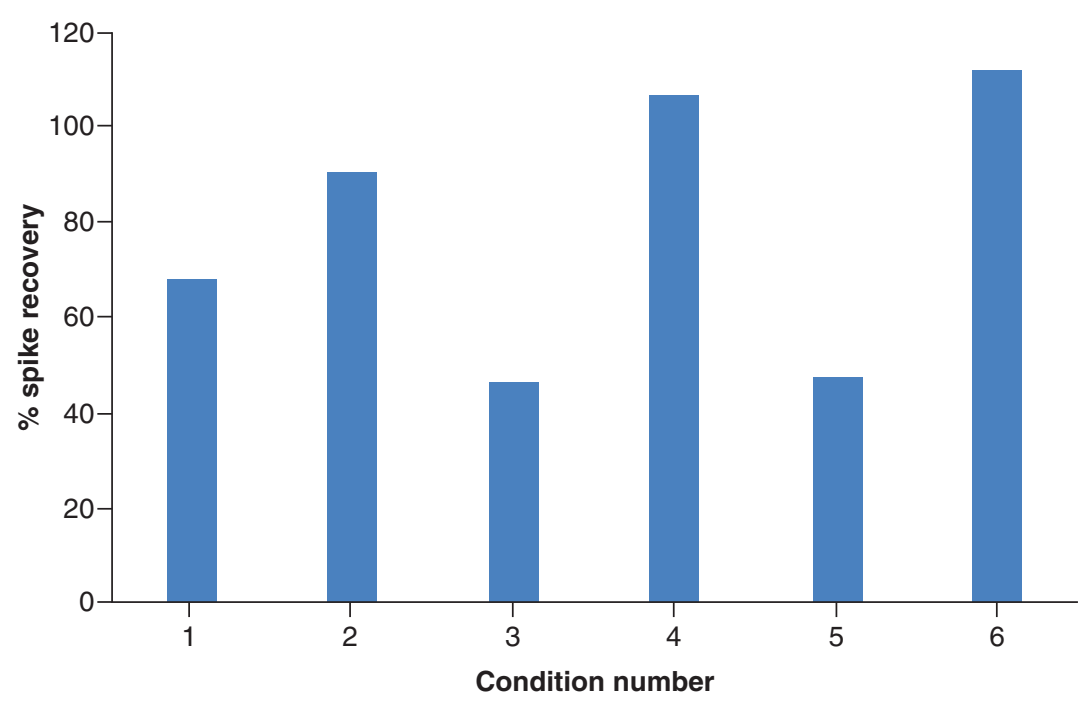

Figure 5. Three bulk drug substance samples (labeled A, B, C) were spiked with 20 p.p.m. polyethyleneimine plus $10^{4} \mathrm{pg} / \mathrm{ml} \mathrm{CHO} \mathrm{DNA} \mathrm{and} \mathrm{treated} \mathrm{with}$ $0.5 \% \mathrm{w} / \mathrm{v}$ SDS $+25 \mathrm{mM} \mathrm{NaOH}$ and DNA quantified by Wako extraction and qPCR quantitation.

1. Product A BDS with 20 p.p.m. PEI 1:100 dilution;

2. Product A BDS with 20 p.p.m. PEI 1:200 dilution;

3. Product B BDS with 20 p.p.m. PEI 1:100 dilution;

4. Product B BDS with 20 p.p.m. PEl 1:200 dilution;

5. Product $C$ BDS with 20 p.p.m. PEl 1:100 dilution;

6. Product C BDS with 20 p.p.m. PEI 1:200 dilution.

In this paper we outline a new method for removing PEl interference in DNA quantitation by several techniques. Both sarkosyl \pm heparin, and SDS in combination with $\mathrm{NaOH}$, proved extremely effective in removing PEI from in-process samples and from BDS. This method has potential application to improving other analytical methods similarly affected by PEl interference, and could be a valuable tool to solve the PEl issue for the biopharmaceutical industry's analytical community.

\section{Author contributions}

S-M Zhang conceived the key idea with additional contribution from G Kilby and M Roberts. S-M Zhang performed the associated lab work and J Zeitler the data integrity check. JR White, M Jones and A Liu reviewed and revised the manuscript. 


\section{Financial \& competing interests disclosure}

The authors have no relevant affiliations or financial involvement with any organization or entity with a financial interest in or financial conflict with the subject matter or materials discussed in the manuscript. This includes employment, consultancies, honoraria, stock ownership or options, expert testimony, grants or patents received or pending, or royalties.

No writing assistance was utilized in the production of this manuscript.

\section{Open access}

This work is licensed under the Attribution-NonCommercial-NoDerivatives 4.0 Unported License. To view a copy of this license, visit http://creativecommons.org/licenses/by-nc-nd/4.0/

\section{References}

1. Zheng WF, Jing L, Lei Q. Development and validation of quantitative real-time PCR for the detection of residual CHO host cell DNA and optimization of sample pretreatment method in biopharmaceutical products. Biol. Procedures Online 21, Article number 17 (2019)

2. Hussain M. A direct qPCR method for residual DNA quantification in monoclonal antibody drugs produced in CHO cells. J. Pharm. Biomed. Anal. 115, 603-606 (2015).

3. Wang X, Morgan DM, Wang G, Mozier NM. Residual DNA analysis in biologics development: review of measurement and quantitation technologies and future directions. Biotechnol. Bioeng. 109, 307-317 (2012)

4. Wang Y, Cooper R, Kiladjian A, Bergelson S, Feschenko M. A digestion-free method for quantification of residual host cell DNA in rAAV gene therapy products. Mol. Ther. Methods Clin. Dev. 13, 526-531 (2019).

5. Taylor SC, Nadeau K, Abbasi M, Lachance C, Nguyen M, Fenrich J. The ultimate qPCR experiment: producing publication quality, reproducible data the first time. Trends Biotechnol. 37(7), 761-774 (2019).

6. Forootan A, Sjöback R, Björkman J, Sjögreen B, Linz L, Kubista M. Methods to determine limit of detection and limit of quantification in quantitative real-time PCR (qPCR). Biomol. Detect. Quantif. 12, 1-6 (2017).

7. Sun C, Tang T, Uludag H, Cuervo JE. Molecular dynamics simulations of DNA/PEl complexes: effect of PEI branching and protonation state. Biophys. J. 100(11), 2754-2763 (2011).

8. Singh N, Arunkumar A, Chollangi S, Tan ZG, Borys M, Li ZJ. Clarification technologies for monoclonal antibody manufacturing processes: current state and future perspectives. Biotechnol. Bioeng. 113, 698-716 (2016).

9. Hunter AC. Molecular hurdles in polyfectin design and mechanistic background to polycation induced cytotoxicity. Adv. Drug Deliv. Rev. 58, 1523-1531 (2006).

10. Moret I, Peris JE, Guillem VM et al. Stability of PEI-DNA and DOTAP-DNA complexes: effect of alkaline pH, heparin and serum. J. Control. Rel. 76, 169-181 (2001).

11. Bertschinger M, Backliwal G, Schertenleib A, Jordan M, Hacker DL, Wurm FM. Disassembly of polyethylenimine-DNA particles in vitro: implications for polyethylenimine-mediated DNA delivery. J. Control. Rel. 116(1), 96-104 (2006).

12. Perez-Berlanga M, Laferriere F, Polymenidou M. SarkoSpin: a technique for biochemical isolation and characterization of pathological TPD-43 aggregates. Bio-protocol 9 (22), e3424 (2019).

13. Hussain M, Bowers J. A droplet digital PCR method for $\mathrm{CHO}$ host residual DNA quantification in biologic drugs. J. Anal. Pharm. Res. 4(3), 00107 (2017).

14. Anderson J, Hussain M. A direct droplet digital PCR method for E. coli host residual DNA quantification. Pharmacol. Pharm. 9, 117-123 (2018). 